\title{
COMPETENT AND PROFESSIONAL PERFORMANCE OF INSURANCE BUSINESS AS A PART OF THE PROTECTION OF THE RIGHTS AND INTERESTS OF INSURANCE SERVICE USERS
}

\begin{abstract}
Insurance represents a business activity which is becoming increasingly important for all trends in society. Namely, all commercial and other activities beneficial to society, by means of an insurance policy, ensure the safety of business, regardless of any risks that may arise. As a result, a competent and professional performance of insurance business, which among other things protects the rights and interests of insurance service users is crucial for this business activity. That is why we, in this paper, put a particular emphasis on the obligations of a competent and professional performance of the insurance business, which are stipulated by the EU Directive on insurance distribution, as well as by the National Bank of Serbia Guidelines on minimum standards of conduct and a good practice for insurance market participants.
\end{abstract}

Keywords: professional insurance, the Directive on insurance distribution, interest of insurance service users

\footnotetext{
* LLM, PhD candidate at the Faculty of Law for Commerce and Judiciary, The University of Business Academy in Novi Sad, Serbia, e-mail: koricasvetlana@gmail.com

${ }^{* *}$ LLM, PhD candidate at the Faculty of Law, The University of Belgrade, Serbia, e-mail: pocucamsara@gmail.com

(c) () (C) 2021 by the authors. This article is an open access article distributed under the terms and conditions of the Creative Commons Attribution (CC BY) license (https://creativecommons. org/licenses/by/4.0/).
} 


\section{Introduction}

Corporate governance is based on the assumption that the overriding principle is the principle of cooperation with everyone. Different persons have different interests in relation to insurance companies (employees, creditors, shareholders, insurance service users...). According to Vasiljević and Petrović Tomić (2020), "the insurance status right is included in Insurance Law" (p. 8). Sometimes, their interest does not have to correspond to the interest of the insurance company as such. In the insurance company business, the protection of insurance service users is defined as a priority, given that article 13 of Insurance Law (2014) stipulates that supervision over the performance of the insurance business is conducted for protecting the rights and interests of insurance service users. The insurance service users, according to Insurance Law (2014), are the insured, policy holders, insurance beneficiaries, and damaged third parties (article 15). In other words, the concept of the insurance service user implies a category of persons broader than consumers, in view of the fact that according to article 5 of Consumer Protection Law (2021), a consumer is defined as a natural person who acquires goods or services in the market for purposes other than his business or other commercial activity, or as pointed out by Nataša Petrović Tomić (2014), "different EU directives define a consumer as a natural person who acquires or uses goods or services for non-professional use" (p. 45). Thus, insurance company management is obliged to act in the company's best interest, taking care to ensure the protection of insurance service users.

We could say that "modern insurance as a form of growth and development risk management appeared along with private ownership development" (Petrović, Njegomir \& Počuča, 2013, p. 731), and that "its primary function does not change with insurance development, that function remains the protection of property and individuals" (Počuča \& Krstinić, 2013, p. 33). However, as Smiljanić and Zarubica (2018) point out, "in the field of insurance trends, we should pay particular attention to the effect of the world crisis on the insurance market" (p. 307), as well as to the risks involved which have gained further momentum with the SARS-CoV-2 virus pandemic, and which, according to Kočović et al. (2020) bring about "devastating social, economic and political consequences" (p. 12).

The protection of insurance service users is achieved, among other things, by the competence and professionality of natural persons dealing with insurance distribution. The definition of insurance distribution is provided in article 2 of the Directive on insurance distribution (2016/97), which states 
that, for the purposes of this Directive, "insurance distribution" means "the activities of advising on, proposing, or carrying out other work preparatory to the conclusion of contracts of insurance, of concluding such contracts, or of assisting in the administration and performance of such contracts, in particular in the event of a claim, including the provision of information concerning one or more insurance contracts in accordance with criteria selected by customers through a website or other media and the compilation of an insurance product ranking list, including price and product comparison, or a discount on the price of an insurance contract, when the customer is able to directly or indirectly conclude an insurance contract using a website or other media".

\section{The obligation of competent and professional conduct of insurance business according to the European Union Directive on insurance distribution}

The Directive on insurance distribution (2016/97) stipulates the obligation of the member states to ensure that insurance and reinsurance distributors and employees of insurance and reinsurance companies, who carry out insurance and reinsurance distribution activities, possess the appropriate knowledge and skills required for the performance of such activities, in order to complete their tasks and perform their duties in an adequate way (article 10).

In addition, the Directive on insurance distribution (2016/97) stipulates in its introductory provisions that it is important to guarantee a high level of professionalism and competence of the persons carrying out insurance distribution activities, and that their continuous training and development should be ensured. In that regard, natural persons involved in insurance distribution must have a good repute, professional knowledge and competence. On analysing this provision further, we can see that it implies the fulfilment of three cumulative conditions among natural persons involved in insurance distribution: that a person has a good repute, that they possess professional knowledge and, as a third condition, that those persons are competent in the conduct of insurance distribution activities. A person has a good repute if they have a clean criminal record, or any equivalent document in compliance with national regulations relating to criminal acts against property or in the field of financial operations, if they have not been declared bankrupt, unless their rehabilitation has been realized in compliance with the national law. Professionality and competence can be acquired by completing a certain educational qualifications degree, or through work experience, and it includes knowledge of insurance activities (insurance market supply, insurance service characteristics, the 
activities to be taken, the rights and obligations of insurance service users, the protection of insurance service users' rights, etc.). Further on, the Directive on insurance distribution (2016/97) stipulates that the Member States guarantee that persons involved in insurance distribution should comply with the continuous training obligation, which implies no less than 15 hours of professional training or development per year (article 10).

Further on, article 17 of the Directive on insurance distribution (2016/97) stipulates that "Member States shall ensure that, when carrying out insurance distribution, insurance distributors always act honestly, fairly and professionally in accordance with the best interests of their customers." In this regard, this principle has two applications, as pointed out by Slavnić (2018): "its primary purpose is for the rules relating to the performance of distributors' duties established by this Directive and the national laws of the member states, to be applied as auxiliary rules of a general value in terms of moral character", and in its secondary application, "the application of this general principle, the effect of which is, according to art. 17 par. 1 of the Directive on insurance distribution, of a compulsory nature, and which may not be excluded or restricted in application by an agreement between the distributor and the client, as is the case with similar, or equivalent principles in the national law of contracts and torts, should serve in cases of need for creating non-existent legal norms for regulating the distributor's relation to the client in carrying out duties concerning clients" (p. 12).

In addition, with regard to this principle under article 17 of the Directive on insurance distribution (2016/97), relating to acting in the clients' best interest, as stated by Petrović Tomić (2019): "Making sure that business complies with the principle of the insurance clients' best interests represents a process, which requires a continuous observance of the principle of acting honestly, fairly and professionally. We are of the opinion that the obligation of acting in the consumers' best interest existed (and still exists) before the adoption of the Directive on insurance distribution (2016/97). It derives from the corporate governance principle, more specifically from the principle of protecting the interests of all the interested parties (the so-called stakeholders)" (p. 251).

Thus, individual obligations introduced by article 17 of the Directive on insurance distribution (2016/97) are: acting honestly, fairly and professionally. Honest and fair acting represents the introduction of the insurance distributor's obligation to act in a moral and honest way in carrying out insurance business. Professional conduct implies the insurance distributor's competence in the conduct of insurance business. 


\section{The obligation of professional and competent conduct of insurance business according to the Guidelines on minimum standards of conduct and good practice for insurance market participants of the National Bank of Serbia}

In our economic conditions, in the last twenty years in particular, "as a result of macro changes, there has been the establishment and development of new financial instruments, the hedging methodology has been improved and the development of corporate governance encouraged" (Dukić Mijatović, 2011, pp. 15-16).

Insurance Law (2014) stipulates in article 19 that "an insurance company, reinsurance company, insurance mediation company, insurance agency company and an insurance agent are obliged to carry on their business in compliance with the law, general acts, business policy acts, rules of the insurance profession and the actuary profession, good business practice and business ethics". In addition, Insurance Law (2014) stipulates the obligation for management members to have a good business repute and the appropriate professional qualifications, knowledge and experience required for a management position (article 62).

According to article 2 of the Company Law (2011), a company is defined as "a legal entity carrying on business with the aim of acquiring profit". In this context, one of the four direct benefits of corporate governance for a company, represented in the Corporate Governance Code (2012), is better reputation, which basically indicates that "in today's business environment, reputation has become a key element of each company's goodwill. A company's reputation practically constitutes an integral part of its assets. Companies which observe the rights of owners and creditors act in a transparent and responsible way, enjoy greater public trust and a stronger goodwill, which leads to greater trust in the company and its products". By way of conclusion in this context, Stojković (2013) states that "good corporate governance is widespread nowadays, as essential for establishing an attractive investment climate, which is characterized by competent companies and efficient financial markets" ( $p$. 46).

Further on, according to the Decision on the procedure upon the complaint of the insurance service user (2021), "an insurance company, insurance mediation company, insurance agency company, natural person - entrepreneur who is an insurance agent, as well as a bank, financial lessor or public post operator conducting insurance agency business subject to prior consent of the National Bank of Serbia in compliance with the law - are obliged to 
ensure the right to information and protection of their users' rights and interests". The restrictive policy of the National Bank of Serbia is also evident in a series of adopted Regulations in the field of supervision over the performance of insurance business (2021).

Furthermore, through Guidelines No. 2 on corporate governance in insurance companies (2021), the National Bank of Serbia suggested to the insurance companies "the way of organizing and carrying out management and supervision activities in order to improve work efficiency, without imposing specific solutions. With that in mind, insurance companies (in particular those with a heterogeneous ownership structure) should adopt the adequate corporate governance policies and practices, and publish an annual statement of corporate governance". In line with the aforesaid, the Commercial Chamber of Serbia established the Education Service with a view to helping company employees to improve the existing and acquire new knowledge and skills, bearing in mind that successful companies build their competence on their employees' knowledge (Commercial Chamber of Serbia, 2021).

In addition, in 2018 the National Bank of Serbia adopted the Guidelines on minimum standards of conduct and good practice for insurance market participants, which define the frameworks and standards of conduct and good business practice in the insurance market. These Guidelines are not designed to be acts for direct application. The Guidelines on minimum standards of conduct and good practice for insurance market participants (2018), which define the frameworks and standards of conduct and good business practice in the insurance market, are intended for insurance companies, insurance mediation companies, insurance agency companies, natural persons-entrepreneursinsurance agents, and other parties conducting insurance agency business on the basis of prior consent of the National Bank of Serbia, and they do not stipulate any timeframe for harmonizing the business of such parties with their provisions.

The Guidelines on minimum standards of conduct and good practice for insurance market participants (2018) stipulate in item 43 that an insurer is expected to ensure that "the employees involved in the activities of creating new, and innovating existing insurance services possess the required qualifications, knowledge and experience in order to adequately understand the basic features and characteristics of a specific insurance service, as well as the interests, aims and characteristics of the target market segment". 
Furthermore, the Guidelines on minimum standards of conduct and good practice for insurance market participants (2018) also stipulate that an insurer ${ }^{1}$ is obliged to provide training and continuous professional development of employees involved in the sale of insurance services and the activities conducted after the sale of insurance services, as well as employees conducting supervision of the performance of such activities (hereinafter: the employees), as well as to conduct regular reviews with respect to the employees' required knowledge and skills.

The Guidelines on minimum standards of conduct and good practice for insurance market participants (2018) stipulate that the insurer should regulate the training and continuous professional development of employees by an internal act, which they shall make accessible to the employees.

Further on, the Guidelines on minimum standards of conduct and good practice for insurance market participants (2018) also stipulate that the duration of the training courses is expected to correspond to the subject matter and the skills to be acquired, and that the training, in terms of professional level and scope, should be equivalent to training for taking the state examination for acquiring the title of authorized intermediary or authorized agent (item 48). An authorized intermediary or authorized agent is obliged to in each calendar year in which they conduct the insurance mediation, or agency business, attent professional training for at least 15 hours, except in the calendar year in which they obtained the authorization to conduct insurance mediation, or agency business, all in accordance with item 16 of the Decision on acquiring the title and training of authorized intermediaries and authorized insurance representatives (2015).

The training and professional development of authorized intermediaries and authorized representatives are conducted by the Commercial Chamber of Serbia according to the Agreement with the National Bank of Serbia (concluded according to item 3 of the Decision on alterations and amendments to the Decision on acquiring the title and training of authorized intermediaries and authorized insurance representatives (2015) from 2017).

The Guidelines on minimum standards of conduct and good practice for insurance market participants (2018) stipulate that the training syllabus

\footnotetext{
${ }^{1}$ The definition of an insurer is provided in item 4 of Smernice o minimalnim standardima ponašanja i dobroj praksi učesnika na tržištu osiguranja [Guidelines on minimum standards of conduct and good practice for insurance market participants] (2018), G.no. 3092 of 20 April 2018 relating to article 3 of Zakon o osiguranju [Insurance Law], i.e. an insurer is an insurance company which is a legal entity with head office in the Republic of Serbia and which is registered in the competent authority register according to the National Bank of Serbia licence for the conduct of insurance business.
} 
should include knowledge and understanding of: the characteristics of insurance services; the users' rights and obligations, i.e. the regulations relating to those rights and obligations; sales and after-sales activities and methods of protection of users' rights and interests.

In addition, the Guidelines on minimum standards of conduct and good practice for insurance market participants (2018) stipulate that when concluding an insurance contract the insurer, or intermediary is expected to act in an honest, non-discriminatory, transparent and professional way taking into account the users' needs, rights and interests (item 51). The definition of an intermediary is provided in item 4, where it is specified an intermediary is a licensed company for mediation in insurance, a company for insurance agency, a natural person-entrepreneur-insurance agent, as well as a bank, financial lessor or public post operator conducting insurance agency business.

\section{Conclusion}

The Guidelines on minimum standards of conduct and good practice for insurance market participants (2018) were adopted because there was a need for the creation "of appropriate preconditions for insurance market participants to prepare for total compliance with European Union regulations in the field of their subject of work, which are expected to be, in the forthcoming period in the Republic of Serbia EU accession process, appropriately implemented in the Republic of Serbia legal system" (paragraph 2, item 2 of the Guidelines), and with the Directive on insurance distribution (2016), one part of which lays down the insurer's obligation for the employees to possess the required qualifications, knowledge and experience in order to properly understand the principal features and characteristics of any specific insurance service, as well as the interests, aims and characteristics of the target market segment, thus, in a broader sense, realizing the protection of the rights and interests of insurance service users.

Namely, as Petrović-Tomić (2019) points out, "the weaker side of insurance contracts is not adequately protected by contract law (which was realized in the EU member states a while ago), it is essential to establish an institutional basis for a supervisory authority which would control if insurance distributors, while selling insurance products, presented those products professionally and objectively. Security instruments in insurance contract law only make sense if the consumer has obtained a coverage which they find beneficial and corresponding to their needs. In our opinion, consumers should be protected against lack of competence, which most often leads them to contracts which 
do not suit their needs, i.e. which are non-beneficial or do not correspond to their needs" (p. 251).

With that in mind, competent and professional performance of insurance business by natural persons involved in insurance distribution, is the basis for undertaking any activities or actions involved in the preparation, conclusion and implementation of insurance contracts.

Further on, the needs, rights and interests of insurance service users are taken into account in the insurer's or intermediary's professional conduct. This is achieved through the competence of the natural persons involved in insurance distribution, i.e. the requirement that the natural persons involved in insurance distribution possess the required qualifications, knowledge and experience which is acquired, inter alia, through training and continuous development. Insurer employees' training includes 'the knowledge and understanding of:

1) the characteristics of insurance services, in particular the term of insurance contracts, the start of insurance, the insured risks and exclusions relating to those risks, the scope of the insurer's liability, the insurance premium structure (the functional premium amount and the overhead allowances, including the functional premium structure) and other important characteristics of the insurance service;

2) the users' rights and obligations, i.e. the regulations defining those rights and obligations, or the procedures of exercising those rights, such as the procedure and timeframes for filing claims and the required documentation, the right to termination of insurance contracts, the right to withdrawal from contracts, and other rights and obligations of users under insurance contracts;

3) sales and after-sales activities, in particular the manner of informing the users in the pre-contract phase and during the contractual relation, and the preparation and conclusion of insurance contracts,

4) the manner of protecting the users' rights and interests, i.e. the procedures of filing complaints and instituting mediation procedures with the National Bank of Serbia" (item 47 of the Guidelines).

Continuous training of employees results in those persons always having the relevant knowledge and skills, which in itself implies that those persons have professional training of at least 15 hours per year. With that in mind, the practice of insurance business provides the following solutions: training and continuous professional development within the insurance company or by attending the appropriate training courses, seminars or combinations of the two, 
to be defined by insurance companies in their internal acts. In any event what remains to be seen is the manner of implementation of provisions stipulated by the Guidelines, the provisions of which apply to insurance companies, insurance mediation companies, insurance agency companies, natural personsentrepreneurs-insurance agents, banks, financial lessors and the public post operator conducting insurance agency business subject to prior consent of the National Bank of Serbia.

\section{Korica Svetlana}

Master prava, doktorantkinja, Pravni fakultet za privredu i pravosuđe u Novom Sadu, Univerzitet Privredna akademija u Novom Sadu, Srbija

\section{Zarubica Sara}

Master prava, doktorantkinja, Pravni fakultet Univerziteta u Beogradu, Srbija

\section{STRUČNO I PROFESIONALNO OBAVLJANJE POSLOVA OSIGURANJA KAO DEO ZAŠTITE PRAVA I INTERESA KORISNIKA USLUGA OSIGURANJA}

REZIME: Osiguranje predstavlja delatnost koja u sve većoj meri postaje značajna za sve društvene tokove. Naime, sve privredne i druge društveno korisne delatnosti, sa polisom osiguranja obezbeđuju sigurnost poslovanja i to bez obzira na rizike koji mogu nastati. Stoga je stručno i profesionalno obavljanje poslova osiguranja, kojim se između ostalog i štite prava i interesi korisnika usluga osiguranja od krucijalne važnosti za ovu delatnost. Upravo iz tog razloga smo, u okviru ovog rada stavili naročit naglasak na obaveze stručnog i profesionalnog obavljanja poslova osiguranja koje su predviđene Direktivom o dstribuciji osiguranja Evropske unije, a potom i prema Smernicama Narodne banke Srbije o minimalnim standardima ponašanja i dobroj praksi učesnika na tržištu osiguranja.

Ključne reči: profesionalno osiguranje, Direktiva o distribuciji osiguranja, interes korisnika usluga osiguranja. 


\section{References}

1. Directive (EU) 2016/97 of the European Parliament and of the Council of 20 January 2016 on insurance distribution/recast/, Official Journal of the European Union, L. Downloaded 2021, February 10 from https://eur-lex. europa.eu/legal-content/EN/ALL/?uri=CELEX:32016L0097

2. Dukić-Mijatović, M. (2011) Korporativno upravljanje i kompanijsko pravo Republike Srbije [Corporate Governance and Companies Business Law of the Republic of Serbia]. Pravo -teorija i praksa, 28 (1-3), pp. 15-22

3. Kodeks korporativnog upravljanja [Corporate Governance Code]. Službeni glasnik RS, br. 99/12

4. Kočović, J., Rakonjac-Antić, T., \& Koprivica, M. (2020). Rizik pandemije: pretnja ili šansa za delatnost osiguranja? [Pandemic risk: a threat or a chance for insurance business?]. Evropska revija za pravo osiguranja, 19 (2), pp. $10-18$

5. Narodna banka Srbije. Propisi iz oblasti nadzora nad obavljanjem poslova osiguranja [Regulations in the field of supervision over the performance of insurance business]. Downloaded 2021, August 10 from https://nbs. rs/sr_RS/drugi-nivo-navigacije/propisi/propisi-osig/

6. Odluka o sticanju zvanja i usavršavanju ovlašćenih posrednika i ovlašćenih zastupnika u osiguranju [Decision on acquiring the title and training of authorized intermediaries and authorized insurance representatives]. Službeni glasnik RS, 38/15 i 11/17

7. Odluka o postupku po prigovoru korisnika usluge osiguranja [Decision on the procedure upon the complaint of the insurance service user]. Službeni glasnik RS 87/21

8. Petrović Tomić, N. (2019). Pravno osiguranja: sistem I [nsurance law: system I]. Beograd: Službeni glasnik RS

9. Petrović Tomić, N. (2014). Nepravične klauzule evropskog ugovornog prava osiguranja [Unfair clauses of European insurance contract law]. Evropska revija za pravo osiguranja, 13 (2), pp. 44-51

10. Petrović, Z., Njegomir, V., \& Počuča, S. (2013). Characteristics of Agricultural Insurance: The case of countries of former Yugoslavia region. Economics of Agriculture, 60 (4), pp. 729-744

11. Počuča, S., \& Krstinić, D. (2013). Historical development of life insurance. Pravo - teorija i praksa, 30 (4-6), pp. 25-34

12. Privredna komora Srbije. Edukacija i treninzi [Education and training]. Downloaded 2021, August 12 from https://usluge.pks.rs/portal/usluge/ kategorija/1004 
13. Slavnić, J. (2018). Obaveza distributera osiguranja da u obavljanju poslova postupa pošteno, korektno i profesionalno [Obligation of insurance distributors to act honestly, correctly and professionally in performing their business]. Evropska revija za pravo osiguranja, 17 (2), pp. 8-27

14. Smiljanić, I., \& Zarubica, S. (2018). Svetska kriza i njen uticaj na tržište osiguranja u zemljama jugoistočne Evrope [The global crisis and its impact on the insurance market in the countries of Southeast Europe]. In: Petrović, Z., Čolović, V. (eds.), Odgovornost za štetu, naknada štete i osiguranje [Liability for damages, damages and insurance] (pp. 307-322). Beograd: Institut za uporedno pravo

15. Narodna banka Srbije. Smernice broj 2 o korporativnom upravljanju u društvima za osiguranje [Guideline No. 2 on corporate governance in insurance companies]. Downloaded 2021, August 12 from https://nbs.rs/ sr_RS/drugi-nivo-navigacije/propisi/propisi-osig/

16. Narodna banka Srbije (2018). Smernice o minimalnim standardima ponašanja i dobroj praksi učesnika na tržištu osiguranja [Guidelines on minimum standards of conduct and good practice for insurance market participants]. Downloaded 2021, February 22 from https://nbs.rs/export/ sites/NBS_site/documents/propisi/propisi-osig/Smernice_Trziste_ Osiguranja_2018.pdf

17. Stojković, Lj. (2013). Pravni aspekti upravljanja rizikom i sistem internih kontrola kao integralni deo korporativnog upravljanja u društvu za osiguranje [Legal aspects of risk management and the system of internal controls as an integral part of corporate governance in the insurance company]. Evropska revija za pravo osiguranja, 12 (3), pp. 46-53

18. Vasiljević M, Petrović Tomić N (2020), Odgovornost uprave akcionarskog društva za osiguranje za sprečavanje nezakonitog poslovanja [Responsibility of the management of a joint stock insurance company for the prevention of illegal business]. Pravo i privreda, 27 (1), pp. 7-39

19. Zakon o osiguranju [Insurance Law]. Službeni glasnik $R S$, br. 139/14 i $44 / 21$

20. Zakon o privrednim društvima [Company Law]. Službeni glasnik $R S$ 36/11, 99/11, 83/14-dr zakon, 5/15, 44/18, 95/18 i 91/19

21. Zakon o zaštiti potrošača [Consumer Protection Law]. Službeni glasnik $R S$, br. $88 / 21$ 